Utah State University

DigitalCommons@USU

Co

Bee Lab

7-22-1913

\title{
Australian Bees. i. A New Crocisa, with a List of the Australian Species of the Genus
}

\author{
T. D. A. Cockerell \\ University of Colorado
}

Follow this and additional works at: https://digitalcommons.usu.edu/bee_lab_co

Part of the Entomology Commons

\section{Recommended Citation}

Cockerell, T. D. A., "Australian Bees. i. A New Crocisa, with a List of the Australian Species of the Genus" (1913). Co. Paper 501.

https://digitalcommons.usu.edu/bee_lab_co/501

This Article is brought to you for free and open access by the Bee Lab at DigitalCommons@USU. It has been accepted for inclusion in Co by an authorized administrator of DigitalCommons@USU. For more information, please contact digitalcommons@usu.edu.

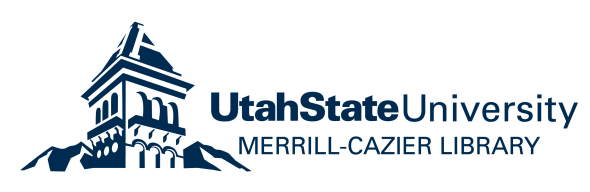


From the Proceedings of the Linnean Society of New South Wales, 1912, Vol. xxxvii., Part 4, October 30th.]

AUSTRALTAN BEES. i. A NEW CROCISA, WITH A LIST OF THE AUSTRALIAN SPECIES OF THE GENUS.

By T. D. A. Cockerell.

(Communicated by W. W. Froggatt, F.L.S.)

[Issued 22nd July, 1913.]

Aymengptera. Apoidea. Anthophoridae: Melectinae-Thyreus (=Crocisa)

$$
\text { Systimatics }
$$


[From the Proceedings of the Linnean Society of New South Wales, 1912, Vol. xxxvii., Part 4, Octuber 30th.]

\author{
AUSTRALIAN BEES. i. A NEW CROCISA, WITH A \\ LIST OF THE AUSTRALIAN SPECIES OF THE \\ GENUS. \\ By T. D. A. Cockerell. \\ (Communicated by W. W. Froggatt, F.L.S.)
}


Crocisa waroonensis, sp.nov.

đ.Length $9 \mathrm{~mm}$., expanse a little over 20. Markings (due to hair) chalk-white; face, occiput and greater part of cheeks covered with white hair, lower part of cheeks and underside of head with black hair; labrum gibbous at sides; ocelli in a straight line; vertex shining, very sparsely punctured; flagellum obscurely brownish beneath; mesothorax shining strongly, unevenly, not densely punctured; anterior third, sides narrowly, and posterior corners of mesothorax covered with long loose white hair; scutellum with sparse small punctures, its posterior margin $\ldots$-like, the posterior middle occupied by a quadrate patch of white hair, twice as broad as long, white hair also extending from beneath the margin; sides of metathorax with long white hair; pleura with the upper half densely covered with white hair, the under side of thorax with scanty black hair; tegulæ black, with very fine punctures, and a patch of white hair in front; wings with the basal half clear hyaline, the apical dark fuscous, clouded or spotted with paler in the region of the cells; third submarginal cell very narrow, but strongly bulging outwardly; anterior and middle tibiæ covered with white hair on outer and posterior side except at apex; hind tibiæ with the apical half free from white hair except posteriorly; middle and hind basitarsi with a little white hair; hind basitarsi flattened and curved; abdomen rather closely punctured, maskor follows : two transversely placed large hourglass-shaped ones on first segment; four spots or patches each on second and third, the inner round, the outer (especially on second) large patches; two large patches each on fourth and fifth; venter with lateral spots of white hair. There is no basal spot on first abdominal segment. 
Hab. - Waroona, Western Australia, April 4, 1908 (G. F. Berthoud). Froggatt, No.210.

This may be compared with $C$. quadrimaculata Rads., which it resembles in the colour of the wings, but $C$. quadrimaculata has the thorax above with nine white spots, and the maculation of the first abdominal segment is different. It is very much smaller than $C$. lugubris Smith.

I give a list of the known Australian species of Crocisa.

i.Blue-spotted Species. For a table, see Entomological News, February 1907, p.46.

C. lamprosoma Boisduval. Queensland.

C. turneri Friese. Queensland and New South Wales.

C. quartince Gribodo. Confused with C. cceruleifrons W. F. Kirby, which is quite distinct.

C. darwini Cockerell. Port Darwin. Blue markings, shining.

C. tincta Cockerell. Toowoomba, Queensland. Markings of abdomen pale blue.

C. beatissima Cockerell. Adelaide. Markings of abdomen bright blue, but not shining.

ii. White-spotted Species. For tables, see Bull. Amer. Mus. Nat.

Hist., xxiii.(1907), p.232; and Entomologist, August, 1910, p. 217 .

C. albopicta Cockerell. Mackay, Queensland.

C. waroonensis Cockerell. Western Australia.

C. rotundata Friese (albomaculata Smith, preoceupied). Mackay, Queensland.

C. lugubris Smith.

C. macleayi Cockerell. New South Wales.

C. quadrimaculata Radoszkowski. New South Wales.

Excluded Species.

The following two blue-spotted species have been considered to be Australian. I have seen them only from Amboina, and do not believe they occur in Australia.

C. nove-hollandice Lepeletier. " New Holland."

C. nitidula Fabricius. 
